\title{
The Chancel of St. Paul's Anglican Church, Halifax, Nova Scotia: Form Follows Convenience?
}

\section{J. Philip McAleer}

Volume 17, numéro 1, 1990

\section{URI : https://id.erudit.org/iderudit/1073155ar}

DOI : https://doi.org/10.7202/1073155ar

\section{Aller au sommaire du numéro}

\section{Éditeur(s)}

UAAC-AAUC (University Art Association of Canada | Association d'art des universités du Canada)

\section{ISSN}

0315-9906 (imprimé)

1918-4778 (numérique)

\section{Découvrir la revue}

\section{Citer cet article}

McAleer, J. P. (1990). The Chancel of St. Paul's Anglican Church, Halifax, Nova Scotia: Form Follows Convenience? RACAR : Revue d'art canadienne / Canadian Art Review, 17(1), 46-53. https://doi.org/10.7202/1073155ar

\section{Résumé de l'article}

Lors de sa construction en 1750, l'église anglicane St. Paul d'Halifax n'était qu'une simple structure rectangulaire dont l'intérieur se divisait en une nef flanquée de bas-côtés surmontés de galeries. Le choeur occupait les travées à l'extrémité de la nef, et était défini seulement par un « mobilier approprié »comme la chaire et la sainte table. Ce ne fut que cent ans plus tard, soit en 1872, que le choeur tel un espace architectural bien définie fut ajouté à l'église sous la forme d'une boîte en saillie à l'extrémité de la nef. Cet ajout à ce moment-là n'était pas une conséquence, même tardive, comme d'aucuns pouvaient s'y attendre, du mouvement ecclésiologique et de sa revendication d'un espace distinct, séparé de celui de la nef, comme étant nécessaire à la bonne marche des rituels anglicans. Son apparition à l'église St. Paul correspond plutôt à un don spontané d'un laïc dont le seul souci était que le clergé ne disposait pas suffisamment d'espace. Son offre, faite lors d'une réunion paroissiale, fut immédiatement acceptée par la congrégation et le clergé sans aucunement discuter des répercussions éventuelles que cette forme pourraient avoir d'un point de vue liturgique ou symbolique, ou encore sans évaluer l'impact de cet ajout sur l'histoire structurale de l'église.

Selon les écrits de l'époque, il semble que seule la question pratique soit venue à l'esprit. On rencontre cette attitude à d'autres occasions lorsque l'on considérait apporter des changements à la structure physique de l'église. Aucun pasteur, marguillier, conseil paroissial ou paroissien n'a apparemment pensé à la signification, la portée ou le symbolisme d'un tel geste. Ceci est par ailleurs démontré du fait qu'à l'époque où l'église fut pour la première fois peinte en blanc à l'extérieur (en 1962), après plus d'un siècle pendant lequel elle fut brune, grise, ou même rouge brique, on ne l'a pas fait en tenant compte de sa couleur originale, de son style palladien, ou encore d'une quelconque influences des églises blanc " colonial » de la Nouvelle-Angleterre ou de son association avec celles-ci. On a plutôt choisi cette couleur pour égayer un endroit très terne du centre de la ville.

Bien qu'il y eut des différends dans l'histoire de l'église pour des questions liturgiques et rituelles, ils apparaissent plutôt isolés de la forme et du style architectural de l'édifice, qui n'étaient donc pas affectés par eux. Cette tradition de l'église St. Paul sert à nous rappeler que, dans l'interprétation de l'architecture, les historiens cherchent trop souvent des explications dans des idées et des idéaux intellectuels et spirituels, lorsque, en réalité, des actions ont été motivées par des préoccupations beaucoup plus terre-à-terre.
Tous droits réservés @ UAAC-AAUC (University Art Association of Canada | Association d'art des universités du Canada), 1990
Ce document est protégé par la loi sur le droit d'auteur. L’utilisation des services d'Érudit (y compris la reproduction) est assujettie à sa politique d'utilisation que vous pouvez consulter en ligne.

https://apropos.erudit.org/fr/usagers/politique-dutilisation/ 


\title{
The Chancel of St. Paul's Anglican Church, Halifax, Nova Scotia: Form Follows Convenience?
}

\author{
J. PHILIP MCALEER \\ Technical University: of Nova Scotia
}

RÉSUMÉ

Lors de sa construction en 1750, l'église anglicane St. Paul d'Halifax n'était qu'une simple structure rectangulaire dont l'intérieur se divisait en unc nef llanquée de bas-côtés surmontés de galeries. Lc choeur occupait les travées à l'extrémité de la nef, et était défini sculement par un "mobilier approprié "-comme la chaire et la sainte table. Ce ne fut que cent ans plus tard, soit en 1872, que lc chocur tel un espace architectural bien définie fut ajouté à l'église sous la forme d'une boîte en saillie à l'extrćmité de la nef. Cet ajout à ce moment-là n'était pas unc conséquence, même tardive, comme d'aucuns pouvaient s'y attendre, du mouvement ecclésiologique et de sa revendication d'un espace distinct, séparé de cclui de la nef, comme étant nécessaire à la bonne marche des rituels anglicans. Son apparition à l'église St. Paul correspond plutôt à un don spontané d'un laic dont le seul souci était que le clergé ne disposait pas sulfisamment d'espace. Son offre, faite lors d'une réunion paroissiale, fut immédiatement acceptée par la congrégation ct le clergé sans aucuncment discuter des répercussions éventuelles que cette forme pourraient avoir d'un point de vue liturgique ou symbolique, ou encore sans ćvaluer l'impact de cet ajout sur l'histoire structuralc de l'église.

Selon les écrits de l'époque, il semblc que seule la question pratique soit venue à l'esprit. On rencontre cette attitudc à d'autres occasions lorsque l'on considérait apporter des changements à la structure physique de l'église. Aucun pasteur, marguillier, conseil paroissial ou paroissien n'a apparemment pensé à la signification, la portćc ou le symbolisme d'un tel gestc. Ceci est par ailleurs démontré du fait qu'à l'époque où l'église fut pour la première fois peinte en blanc à l'cxtérieur (en 1962), après plus d'un siècle pendant lequel elle fut brune, grisc, ou même rouge brique, on nc l'a pas fait en tenant compte de sa couleur originale, de son style palladien, ou cncorc d'une quelconque influcnccs des églises blanc "colonial " de la Nouvelle-Angleterre ou de son association avec celles-ci. On a plutôt choisicette couleur pour égayer un endroit très terne du centrc de la ville.

Bien qu'il y eut des différends dans l'histoire de l'église pour des questions liturgiques et rituelles, ils apparaissent plutôt isolés de la forme et du style architectural de l'édifice, qui n'étaient donc pas affectés par eux. Cette tradition de l'église St. Paul sert à nous rappeler que, dans l'interprétation de l'architecture, les historiens cherchent trop souvent des explications dans des idées et des idéaux intellectuels et spirituels, lorsque, en réalité, des actions ont été motivées par des préoccupations beaucoup plus terre-à-terre.
The emphasis placed on the architectural form of the chancel in the mid-nineteenth century, primarily as a result of the Ecclesiological movement and its concern for the proper celebration of the restored and revived liturgy in the Anglican Church, is a well-established fact familiar to historians of architecture. The doctrine-or dogma - promoted by the Cambridge Camden Society (after 1846, the Ecclesiological Society), and spread through its publication the Ecclesiologist, advocated a distinct structural space for the chancel. Preferably, it should be long, and lower and narrower than the nave, creating a clear visual separation of the chancel from the nave on the interior as well as on the exterior. ${ }^{1}$

This emphasis and these particular forms are primarily associated with the Gothic Revival movement and, of course, also with the architecture and theories of A. W. N. Pugin (1812-52). ${ }^{2}$ While Pugin's concern for correctness in all things relat- 
ing to the proper conduct of architecture may be said to have led to his conversion to Catholicism in $1835,{ }^{3}$ his embrace of the architecturally distinct chancel was also supporled by Anglicans, albeit with a certain degree of chagrin. ${ }^{4}$

These matters of correctness of form were not totally remote from the seemingly distant "Colonies." After the Anglican cathedral was established at Fredericton, New Brunswick, the ideas and ideals of the Ecclesiologists affected the course of its construction, especially under the auspices of its first bishop, Rt. Rev. John Medley, between 1845 and 1853 . The cathedral was first designed by Frank Wills (b. 1827) on the model of the parish church of St. Mary's, Snettisham, Norfolk. However, before the chancel was constructed there was a change of architect. William Butterfield (1814-1900) was consulted and designed a new one that -in recognition of the church's cathedral status - had a roof equal in height to the nave's. The bishop further "improved" the new design by lengthening the chancel. The cathedral of New Brunswick thereby became one of the primary exemplars of Ecclesiologically correct cathedral church design in North America. ${ }^{6}$

It is thus with some interest that one turns attention to St. Paul's Halifax, as it was the Anglican cathedral of Nova Scotia between 1787 and $1864 .^{7}$ It had been built in $1750,{ }^{8}$ the year after the founding of the town: provision for a church had been included in the earliest plans showing the layout of the new town as a grid pattern of rectangular blocks. ${ }^{9}$ In these plans, an oblong open space, the Parade Ground, is located at the centre of the town: a church is indicated at the south end of it, a court house at the north. Ultimately, the church was built at the south end. Perhaps because of the slope of the hill, it was oriented north-south, with the chancel at the south, and the main entrance facing the Parade. As erected in 1750 (Fig. 31) the interior was apparently not finished until the early $1760 \mathrm{~s},{ }^{10} \mathrm{St}$. Paul's was and is a somewhat schizophrenic building. The exterior was modelled on St. Peter, Vere Street, a church known at that time as Mary'bone Chapel (Fig. 32). It had been designed by the architect James Gibbs (1682-1754) between 1721 and 1724, about the same time as Gibbs's grander, more famous St. Martin-inthe-Field (1721-26). ${ }^{11}$ St. Paul's was apparently quite a tolerable translation of the brick and stone St. Peter into wood-even including the imitation of the angle quoins. ${ }^{12}$ On the inside, in contrast, the design bore absolutely no relation to Gibbs's St. Peter, Vere Street or to any other of his churches, which are all distinguished by the use of giant columns placed on high pedestals, rising uninterrupted from floor to ceiling vault, passing in front of the galleries over the aisles. Rather than giant columns, in St. Paul's we find two tiers of square supports, the lower piers joined by a horizontal entablature under the galleries, and the upper (fluted) ones rising from pedestals interrupting the gallery frontals and joined by an arcade of depressed arches under the springing of the (plaster) barrel vault (Fig. 33). This system is similar to that employed by Christopher Wren (1632-1723) in several of his London churches, ${ }^{13}$ and is also found in North America in Christ Church, Boston, ${ }^{14}$ and Trinity Church, Newport, ${ }^{15}$ both about a quarter century earlier than St. Paul's, Halifax.

An even more emphatic departure from, or rejection of, St. Peter, Vere Street and Gibbs's usual planning is found in the plan and interior spatial arrangements (Fig. 34). Both were of extreme simplicity in St. Paul's. The rectangular box was divided for its full length into nave and aisles, with galleries over the aisles: entrance from the north was made directly into the nave. More significantly, a chancel was created at the south end simply by the placement of furniturecommunion table, reading desk, pulpit - in the last bay of the nave (Fig. 35). This disposition again was like many of Wren's churches, as well as the Boston and Newport churches, and quite unlike Gibbs's typical handling as evidenced in St. Peter (Fig. 32). There entrance is made via three portals leading either through a narrow vestibule or through larger flanking rooms containing the stairs to the galleries. At the east or sanctuary end there are also flanking rooms at the ends of the aisles with rooms above them. Moreover, between these double stacks is an architecturally defined chancel: separated from the nave by an arch, the space is a little narrower than the nave and is vaulted at a lower level. Except for its relative shallowness, the form of the chancel probably would have satisfied an Ecclesiologist of the next century: certainly, the arrangement at St. Paul's would not.

Thus, for reasons not hinted at in contemporary accounts, the convention of a separate chancel current in mid-eighteenth-century architecture was spurned in favour of a more old-fashioned solution. It was to be well over a century before this situation was modified and then, it appears the motivation was less liturgical correctness or symbolic propriety than practicality.

During the century following its completion, St. Paul's underwent only two significant alterations, both being expansions of the original rectangular box. An entrance vestibule containing new, more ample stairs to the galleries, and two rooms to be used as vestries were added at the north façade in 
1812 (Fig. 36) ${ }^{16}$ In 1868 , the church was enlarged again, this time laterally by the addition of an outer pair of aisles, the solution to a chronic shortage of pews (Fig. 37). ${ }^{17}$ Both of these additions were made for reasons of convenience. It is with some surprise that one notes there was no discussion about constructing a separate chancel during the $1840 \mathrm{~s}, 1850 \mathrm{~s}$, or $1860 \mathrm{~s}$ as a reflection of the ideas promulgated by the Ecclesiologists. Indeed, when a chancel was finally added in 1872 , it too came as a result of concerns about "convenience," and appears rather as an afterthought in the wake of the enlargement of 1868 .

According to the Minute Books of the wardens and vestry of St. Paul's, the addition of a chancel was the gift of one of the members of the church, Mr. Edward Binney. Judging from the record of the annual parish meeting on 1 April 1872, Mr. Binney made the offer spontaneously. It was then immediately and unanimously approved by the parishioners without any discussion. It is worth quoting the minutes:

Edward Binney asked permission of the Chairman to make a few remarks. He said he had long felt the great want of a proper Vestry and Chancel at St. Paul's; and observed the inconvenience that the officiating clergy were subjected to, in consequence. To remedy this, he said that if a Chancel were erected, under the supervision of the Church Wardens, it would afford him great pleasure to provide the means, therefore, himself, and hoped that the Meeting would accede to his wishes.... Mr. Binney's offer was put to the meeting for their acceptance and was passed by acclamation. ${ }^{18}$

Accepting this record at face value, the addition of the chancel was made at the suggestion of a layman to give the clergy more room. There is no evidence in the minutes or in the annual reports of the rector that a new and proper chancel was desired for the reasons advocated by Pugin and the Ecclesiologists - or for any other. ${ }^{19}$ The discussions about enlarging the church took place within the framework of the need to accommodate a growing congregation and never touched on what could have been a related requirement, a larger space for the clergy to conduct the service. The addition of the chancel, although not premeditated, nonetheless conformed to traditional concerns at St. Paul's, which emphasized practicality rather than ideological or symbolic values and showed no awareness of contemporary ideas about appropriate architectural form.

The new chancel, 28 feet long, was squarish in plan with a barrel vault and an arch lower than the nave's (Figs. 38-39). It was flanked by two narrow rooms or wings, ${ }^{20}$ with the interior side walls of the chancel enlivened by two large blind arches with Corinthian pilasters. The south wall was domi- nated by a large semicircular-arched window with Romanesquoid tracery of three lights supporting encircled quatrefoils above. Except for the form of this window, the new chancel's height, width, depth, and relationship to the nave and aisles strongly resembled the arrangements typical of Gibbs's churches. It is rather ironic that a century after its construction, the design of the interior of St. Paul's at last acquired a certain Gibbsian quality-although, from this point of view, the exterior "temple" form was now compromised by the projection of the separate and distinct rectangle of the lower chancel (Fig. 40, cf. Fig. 32). This aspect was probably less a reflection of specific Ecclesiological values than the result of a certain economy of form and construction necessary to the process of making an addition to a wide oblong box-like form.

It is interesting to discover that when the Anglican bishop of Nova Scotia, Rev. Hibbert Binney (1851-87), chose the parish church of St. Luke as his cathedral church, he immediately set about the construction of a long chancel as an addition to that building. That was in 1864, well before any expansion of St. Paul's had been discussed. ${ }^{21}$ St. Luke's, designed by John MacPherson, was built between 1846 and 1848 in the Gothic Revival style. ${ }^{22}$ It was a wooden structure with an axial west tower and galleries over the aisles on the interior. ${ }^{23}$ Its new chancel was long and narrow, with a large traceried window at the south (like St. Paul's, St. Luke's was oriented north-south). As the bishop himself made clear in a charge delivered to a diocesan synod held at St. Luke's on 3 July 1866 , the enlargement and alteration of St. Luke's by the addition of a chancel "rendered it more suitable than any other church in the Diocese for a Cathedral." ${ }^{24}$ The bishop, in this respect at least, seems to have held "up-to-date ideas." 25

A similar lack of concern for the appropriate forms necessary to the "proper conduct" of the liturgy as it was conceived of in the mid-nineteenth century seems to have been typical of St. Paul's with respect to the appointments of the chancel as well. References to the acquisition of new furnishings for the sanctuary or their placement are laconically reported in the Minute Books; never is there any hint of a significant discussion. The rector, wardens, and vestrymen spent much time discussing the maintenance of the church. They dealt with problems such as heating or the installation of gas or electric lighting and patiently sought various options and tenders for these ongoing practical concerns. Such attitudes seem to have had a long history at St. Paul's.

As far back as 1787, it is simply reported in the minutes that the pulpit should be "removed 
nearer to the Middle Aile [sic]." ${ }^{26}$ The bishop at that time, Rev. Charles Inglis (1787-1816), remarked in a letter (1 March 1788) to the Archbishop of Canterbury only that "the pulpit of the Church in Halifax was inconveniently situated, being too near one of the galleries." 27 Somewhat later, in 1792, the vestry decided to cut back the pews "so as to make the passage to the Middle Isle [sic] more convenient." 28 No mention is made of the acquisition of furniture for the sanctuary between 1760 and the construction of the chancel in 1872. An extensive reorganization of the chancel, however, had been carried out in 1859 , but in spite of the work involved, it was not discussed by the vestry. It was partially reported in the local newspapers, and the results can be seen in the first view of the interior of the church, a photograph taken by Wellington A. Chase, ca. 1859-68 (Fig. 35).

Of these alterations, the rector, Dr. G. W. Hill (1865-85), had this to say:

As regards the alterations at St. Paul's, on which I spent a considerable amount of time, the answer is very simple. The greater part of the alteration was purely utilitarian. Whatever ornament was added, such as a better reading desk, had no symbolism in it, and could not possibly be construed into have any such meaning.

This statement was made in the course of an acrimonious exchange of letters between the rector and Bishop Binney in which, among other things, Hill had initially protested changes in the communion table favoured by the bishop. ${ }^{29}$ Hill accused the bishop:

There is meaning in all these things, or they are mere puerilities, simple child's play; and as I believe that every intelligent man would indignantly repudiate the charge that he intended to trifle with God, the only alternative is that they are emblematic, or symbolic truths or supposed truths. ${ }^{30}$

The bishop defended his changes on the basis of convenience, specifically denying, for instance, that any "particular signification can possibly be attached" to any of the ornamentation (of an altar cloth) and further remarked:

Why did you give so much time and attention to the alterations in St. Paul's? .. . You would probably answer, that when there are several ways of doing anything one ought to take pains to find the best; that it is right to have everything appropriate to the purpose for which the building is intended; and that the new furniture is more suitable than the old. Can you not believe that others are influenced by the same, or equally, good motives, and refrain from imputing sinister intentions to others, who had done less in this way than you have. ${ }^{31}$

Against this background, it is not surprising to find a lack of evidence for any discussion about the style of the new chancel and its furnishing at the time the chancel was added, since both rector and bishop denied any symbolic meaning. ${ }^{32}$

Yet, on the other hand, considering the venerable age and tradition of the church, it is interesting that there appears not to have been any discussion of style as an aesthetic factor, and specifically the appropriate style for a building of the architectural forms of the mid-eighteenth century. ${ }^{33}$ This is true not only in 1872 but also in the period between that date and 1900, during which all the chancel furnishings were replaced. The fact that they did not indeed give any consideration to this more superficial aspect of style is revealed by old photographs that show a new pulpit acquired in 1886 to have been neo-Gothic in detail, ${ }^{34}$ as was a new stone font (which still exists) donated earlier, in $1873 .^{35}$ The choice of a style that might have been thought incompatible with the fundamental sub-Baroque forms of the church can be seen as a reflection of contemporary taste rather than ideas.

In these latter instances, fashion seems to have outweighed any ideas of appropriateness. The same seems to be true of the south window of the new chancel. Under its classical frame, the mullions recall Gothic tracery even if the pointed arch is avoided: a case of evocation rather than specific allusion. This window was filled with dark stained glass (with texts but not figures), which once more seems incongruous considering the classical forms of the chancel ${ }^{36}$ But again, any perception or discussion of "style" and its possible connotations, especially with regard to Gothic and its association with extreme "High Church" tendencies, is lacking in the records.

New furniture acquired between 1893 and 1905 was without exception donated by prominent members of the congregation. ${ }^{37}$ The choice of style, as well as the shape and particular object, seems to have been entirely the decision of the donor. The gifts are simply recorded in the vestry minutes; there is no hint of the need for a particular item of liturgical furniture, nor of any discussion with a prospective donor. Nor does it seem any donor even applied to the vestry for permission, authorization, or approval of the intended gift.

Considerations of practicality and convenience appear to have prevailed even as late as 1908-1909 when a new and larger organ was purchased, necessitating alterations to the side arches and rooms flanking the chancel. At that time, some discussion took place about the possibility of extending the chancel to the street line. ${ }^{38}$ The reasons for wanting to do so are not made clear, but there was apparently a felt need once again for more room, perhaps to accommodate the pews for the choir. Eventually, the extension was not made 
for practical reasons: it would have either contravened city regulations or been too expensive if it conformed with them. ${ }^{39}$ Ironically, it is only at this time that reverence for the original structure briefly - and belatedly - surfaces. The chair of the Organ Committee, W. A. Major, stated in an undated memo as one argument-but not the primary one-against extending the chancel: "Again, there is the danger in moving the chancel back to the street line, the destroying $[\mathrm{sic}]$ of the architecture of the old church and this would probably be objectionable to a great many of the parishioners."

Yet in 1908, the "old" architecture which would have been destroyed was the south wall of the chancel erected only in 1872! Furthermore, by 1908 most of the exterior of the eighteenthcentury building had disappeared - without protest at any time. Far more damage to the "old" architecture of the church than could be done in 1908 was done in 1868 when the outer aisles were added; in 1869, when the upper (gallery) windows were changed (to "match" the new lower ones); and in 1872, when the addition of the chancel eliminated the last vestige of the exterior of the original building of 1750 .

A similar apparent lack of concern for the significance of form may also be noted in the decoration of the church, particularly the selection of the exterior colour scheme. The church is now painted white - with the exception of the steeple, which has been covered in copper since 1926. It might be assumed that this colour represents either a continuous tradition, or an identification with white "Colonial" churches, or a reflection of notions about the suitable colour for a Georgian building. In actuality, such considerations seem not to have been contributing factors to the selection of a colour.

The painting of the fabric, as part of its maintenance, was a constant preoccupation of the wardens and vestrymen from the very beginning. But the colour scheme of the exterior never occasions any discussion. The colours used are not even mentioned; only in later decades is there an occasional reference to the choice of colour being left up to the members of the appropriate committee. ${ }^{40}$ Judging form early nineteenth-century watercolours, the church was then a yellowish white. ${ }^{41}$ By the mid-nineteenth century and the earliest photographs, it is clear that a change had taken place: ${ }^{42}$ darker colours, often with contrasting trim, prevailed for more than a hundred years. It is during this century that there is some record of the colours for the first time; "battleship grey" in $1937 ;^{43}$ a brick red with white (or off-white?) trim in $1949 ;{ }^{44}$ and finally, in 1962 , all white. ${ }^{45}$
The choice of white apparently was made without any reference to its being close to the original colour, or even of its appropriateness to a Georgian church, in the manner of the white "Colonial" churches of New England. ${ }^{46}$ Rather, the primary motivation seems to have been brightening up the church and thus helping to relieve the dullness and drabness of the downtown area in which it is located. ${ }^{47}$ After the church was painted white, however, there was clearly some regret, as the colour proved rather impractical. The exterior was so dirty after a few years that it required either cleaning or repainting. It was then considered that the church ought to be repainted another colour: any colour except white. ${ }^{48}$ Nonetheless, the church is still white today, and recently was once more repainted white; the reasons for retaining the white colour in spite of its impracticality, however, are nowhere apparent in the minutes.

It may be that the minutes are not the place to expect a serious discussion of liturgical correctness or the symbolic content of style or colour. Yet other matters of less import received extended or careful consideration, and disagreement may be detected in still others, even if its nature is not fully spelled out. There was a controversy between the rector, Dr. Hill, and Bishop Binney in the 1860s (separate from the one about the new furniture) about the use of the traditional black gown, rather than the surplice, in the pulpit. ${ }^{49}$ Placing a shelf within the communion rails on which to put the Elements before Communion was also a contentious matter in the last century. ${ }^{50}$ In this century, the surplicing of the choir occasioned lengthy consideration and strong opinions over a period of 11 years. ${ }^{51}$ More recently, even removing a few rows of pews from the back of the church has been seen as a potential source of contention. ${ }^{52}$ The possibility of an underground extension to the church for various church facilities, although agreed to by the vestry, was another issue that raised some strong expressions of opposition from members of the congregation a decade ago. ${ }^{53}$

Thus it seems not too extreme to suggest that questions of form which architectural historians might think significant and of high seriousness were philosophically of little import to the rector, wardens, vestry, and congregation. At least, that is the firm impression one gets from reading through the Minute Books of St. Paul's from 1759 to the 1980s. Quite consistently, the primary concerns of the wardens and vestrymen were questions of practicality and convenience. Those were the major factors behind all the alterations and changes to the structure.

The apparent insouciance of the administrators of St. Paul's with regard to the possible symbolic 
implications of the fabric and furnishings of the church during the nineteenth century and well into the twentieth may serve as a caution against excessive interpretation of the significance of form. In other words, one sees at St. Paul's a separation between actual liturgical practice or customsperformance-about which strong ideas were held, and the style or form of the physical context. There was apparent indifference to the meaning concrete forms can convey or suggest.

It may be that more often than not, in the history of architecture, things were, and are, done for quite mundane reasons. People make routine decisions and carry out work oblivious to, even innocent of, any theoretical discussion. Such a conclusion may be a heavy burden to place upon St. Paul's, Halifax. But its very ordinariness suggests that form typically follows convenience and that buildings that epitomize theory are the exception. At the same time, it can be observed that at St. Paul's a regard for tradition did not extend to the actual building (as opposed to liturgical performance): changes to the original structure that now would cause a great outcry were fearlessly made without opposition..$^{54}$

\section{NOTES}

1 The formation and early years of the Cambridge Camden Society are succinctly summarized in Phoebe B. Stanton, The Gothic Revival E American Church Architecture: An E.pisode in Taste, 1840-1856 (Baltimore, 1968), 3-29 (Chap. I).

2 For Pugin in particular see H.-T. Hitchcock, Early Victorian Architecture in Britain, 2 vols. (New Haven, 1954), I, 56-96 (Chap. III), and Phoebe Stanton, Pugin (London, 1971), esp. 43-44, and 79-124 (Chap. Iv).

3 Stanton, Pugin, 10.

4 For the problems created for the members of the Cambridge Camden Society by Pugin's Catholicism and his anticipation of their theories, see Stanton, Gothic Revival, 19-22, 26, and Stanton, Pugin, 127-28.

Pugin's design for the church of St. Oswald's, Liverpool (1839-42), for instance, anticipated the Society's own advocacy of the English parish church of the Decorated period as the "model" (Hitchcock, Early Victorian Architecture, I, 73-74).

5 Indeed, the Society was at pains to draw up specific instructions particularly for colonial territories: Stanton, Gothic Revival, 3-4, 16-17, 28, 53.

6 For Christ Church Cathedral, Fredericton, see Stanton, Gothic Revival, 127-58 (Chap. Iv). A chancel equal in height to the nave was considered appropriate for a cathedral, as opposed to a parish church. For the enthusiasm of the American E.piscopal church for the Gothic style as wcll as Stanton, sec also William H. Pierson, Jr., American Buildings and their Architects, II. Technology and the Picturesque: the Corporate and the Early Gothic Styles (Garden City, NY, 1975) (Chap. Iv).

7 The first Anglican bishop of Nova Scotia, Rev. Charles Inglis (1734-1816), was consecrated (at Lambeth Palace, London) in 1787: he arrived in Halifax in October of that year. Bishop Hibbert Binney (1819-87) transferred his episcopal scat from St. Paul's to St. Luke's (originally built as a chapel of ease) in 1864. See Reginald V. Harris, The Church of St. Paul in Halifax, Nova Scotia: 1749-1949 (Toronto, 1949), 98-101, 205-207.
8 This is testified by letters of the first governor, Hon. Edward Cornwallis, and of the first missionary sent out by the Society for the Propogation of the Gospel in Foreign Parts (hereafter S.P.G.), Rev. William Tutty: see Harris, St. Paul's, 14-15, 18; for Tutty's letters, see "Letters and Other Papers Relating to the Early History of England in Nova Scotia," Collections of the Nova Scotia Historical Society, VII (1889-91; facsimile edition, Belleville, Ontario, 1977), 89-127, esp. 107, 114, 116 .

9 There are four manuscript plans dated to 1749. Two are in the British Library, Map Library, King George III Topographical Collection: K. Top. cxix.77[76] ("Project for fortifying the Town of Hallefax [sic] in Nova Scotia") is by John Brewsc, engineer; the other, K. Top. CxIx.73 " A Plan of Chebucto Harbour with the Town of Hallefax") is by Moses Harris, surveyor; see Catalogue of the Manuscript Maps, Charts and Plans... in the British Museum (1841, rep. 1962), 553. The other two are in the Public Record Office, London; MPG 803, again by John Brewse, is very similar to B.L., K. Top. cxix.77[76]; the second, MPG 292 ("A Plan of the town of Hallefax in Nova Scotia Augt 1749"), is in a similar hand to MPG 803; see P. A. Penfold, ed., Maps and Plans in the Public Record Office, II, America and West Indies (London, 1974), 201, nos. 1169 and 1168 respcctively.

A number of engraved plans or maps were published in 1749 and 1750 as well.

10 The provincial legislature (General Assembly) voted $£ 1200$ towards the completion of St. Paul's in 1762 (letter of the lieutenant governor of Nova Scotia, Jonathan Belcher, 14 January 1762, to the S.P.G.) (George W. Hill, "History of St. Paul's Church," Collections of the Nova Scotia Historical Society, I [1878; facsimile edition, Belleville, Ontario, 1976], 43-44).

11 For Gibbs see Terry Friedman, James Gibbs (Ncw Haven and London, 1984), esp. 7j-76 for St. Peter, Vere Strect.

12 St. Peter was published in two plates by Gibbs in his $\Lambda$ Book of Architecture (London, 1728); pls. xxIV and xxv. The plates, which present a plan (north) side elevation, west front, and cross section, were probably the main source of information for the North American builders.

13 Most relevant to St. Paul's are St. James, Piccadilly (1682-84), St. Andrew Holborn (1684-90), and St. Andrew-by-the-Wardrobe (1685-93). For Wren's I.ondon churches in general see Kerry Downes, Christopher Wren (London, 1971), 141-55 (pl. 70); for this particular type of decision see John Summerson, Architecture in Britain, 1530-1830 (Harmondsworth, England, 1953 land later editions]), 132.

For a detailed discussion of the relationship of the design of St. Paul's to the architecture of Wren and Gibbs sec J. P. McAleer, "St. Paul's, Halifax, Nova Scotia and St. Peter's, Vere Strect, London (England)," Journal of Canadian Art History, vII, 2 (1984), 113-37 (unfortunately published with a large number of typographical mistakes due to an inattentive editor; a partial list of errata appcars in vilı, 1 [1984], 140).

14 For Christ Church, Boston, of 1723, see Harold W. Rose, The Colonial House of Worship in America (New York, 1963), 215-26 (no. 96), and William H. Pierson, Jr., American Buildings and Their Architecls: The Colonial and Neoclassical Styles (Garden City, N.Y., 1970), 98-100.

15 For Trinity Church, Newport, of 1725-26, see Rose, Colonial Houses, 410-11 (no. 267); Pierson, American Buildings, 101-102; and Norman M. Isham, Trinity Church in Newport, Rhode Island (Boston, 1936), esp. 37-49.

16 The tower and spire were rebuilt following the original design exactly, although the design of the main body of the façade was altercd in two respects. The projecting porch in front of the main door was reduced in size, allowing the insertion of a Venctian window (probably modelled on the one then at the north end of the church) above it to light the new vestibule. 
17 Minute Books of the Wardens and Vestry of St. Paul's Church, Halifax (hereafter "Minute Books"), v (8 April 1844-13 April 1871 [not paginated], 4 and 12 August 1868, 29 March 1869).

18 "Minute Books," vi (25 September 1871-25 March 1886 [stamped pagination]), 12.

19 This is all the more puzzling because the third bishop of Nova Scotia, Rt. Rev. John Inglis (1825-50) became a patron of the society in 1839. See Stanton, Gothic Revival, 14, n. 15, 31 (Edward Jacob Boyce, A Memorial of the Cambridge Camden Society, Instituted May, 1839 and the Ecclesiological [Late Cambridge Camden] Society [London and Cambridge, 1858])

20 Exit was made through part of these rooms from the original south portals of the aisles which remained in use. The remainder of the space in the east wing must have been largely occupied by the mechanism of the (new) organ which was installed on that side of the choir; the corresponding space of the west wing was apparently used as a robing room for the choir.

21 Bishop Binney, who was influenced by and sympathetic to the Oxford "Tractarian" movement, found himself in conflict with the rector (Dr. George W. Hill, 1865-85) and congregation of St. Paul's over such matters in the conduct of the service as wearing the black gown in the pulpit and placing the Elements on the Communion table before the beginning of the office. St. Paul's also strongly opposed the institution of a diocesan synod (synod organization had been agreed to at the Conference of the Bishops of British North America held in Quebec in 1851) but the bishop's will finally prevailed with the provincial legislature in 1864 (having failed in 1863). See Harris, The Church of St. Paul in Halifax, 201-202, 212-13, and Charles Henry Mockridge, Bishops of the Church of England in Canada and Newfoundland (Toronto, 1896), 143-45.

22 Halifax Sun, 6 August 1845, 2.

23 St. I.uke's was complctely destroyed in a fire, 14 December 1905. There are a few photographs of the exterior and interior, after the addition of the chancel, in the Public Archives of Nova Scotia, Halifax.

24 He went on to point out that it was of little credit to the oldest Anglican diocese in North America that there was not a stone cathedral (Hibbert Binney, A Charge Delivered to the Clergy at the Visitation Held in the Cathedral Church of St. Luke's, at Halifax, on 3rd day of July 1866 [Halifax, 1866], 4, 5).

These sentiments were echoed in a letter from the rector of St. Luke's, Rev. William Bullock, 20 January 1865, to the S.P.G. (S.P.G.F.P., "Letters Received - Originals," vol. E 16 , p. 559): "During the past year, we have been engaged in building a suitable chancel which has been furnished with its appropriate Throne and Stalls, but although greatly improved, it is still both in material and construction quite inadequate as the Metropolitan Church."

A new stone cathedral, on a different site, was finally begun in 1907: it was designed by the New York firm of Cram, Goodhue and Ferguson (the official architect was Bertram Grosvenor Goodhue [1869-1924]) and opened in 1910, dedicated to All Saints.

25 The bishop, however, did not specifically advocate the (neo-)Gothic style and he declared himself a staunch guardian against any tendencies towards Romanism, associated with those in England described at the time as Ritualists." See below, nn. 31, 33

26 "Minute Books," III (29 September 1784 - 7 September 1801 [not paginated]), 4 September 1786. It was from about ca. 1780 that, in England, axially placed (two- or three-decker) pulpits were removed or moved to one side.

27 Memoirs of Bishop Inglis of Nova Scotia: "Brief Notes or Me moirs of the Public \& Various other Transactions: taken to assist my memory \& begun Jan 1775" (Public Archives of Nova Scotia, microfilm C23).

28 "Minute Books," III, 26 June 1792

29 Hibbert Binney, A Pastoral Letter including a correspondence between the Rev. Geo. W. Hill and Himself (Halifax, 1866), 29 (letter of 12 November 1866). The alterations referred to were carried out under the rector, Ven. Robert Willis (1825-65)

The controversy did not extend to matters of architectural form or style; with regard to furnishings, it centred on the use of a stand that could be confused with a credence table, and the height and covering of the Communion table

30 Binney, A Pastoral Letter, 6 (letter of 25 October 1866).

31 Binney, A Pastoral Letter, 13, 14 (letter of 5 November 1866). The "sinister intentions," of course, are the emblematic or symbolic ones imputed by Hill. In his response to the various charges of Hill, the bishop was always at pains to disassociate himself from the "Ritualists" - by which both he and Hill apparently meant those in the Ecclesiological movement, or related to it, who advocated any liturgical practices that had any associations with or similarities to Roman Catholic ones

32 The need to put in a new pulpit, and to change the reading desk, was briefly expressed in a vestry meeting more than a decade later, 12 June 1885 ("Minute Books," vI, 448). This is understandable, as the new furnishings placed in the chancel in 1872 were of extreme modesty.

33 The statements made by Bishop Binney concerning style are very general, even vague, and certainly do not advocate any particular style as appropriate for church architecture. In his charge of 1866 (see above n. 24), he briefly touched upon the subject: "The architecture, and all the decorations of a Church, should be so distinctive and peculiar that wherever the eye may turn, it may light on something to recall the wandering mind to the object proposed in going there ... the style of decoration shall bc in all respects suitable to a sacred edifice" (6).

34 It was a polygonal pulpit raised on a high pedestal, purchased from McEwan \& Co., for \$182.07: "Minute Books," viI (6 April 1886-27 March 1899 [partly paginated, to 431]), 37 (28 October 1886); 38, 40, 41 (24 November 1886); and 46 (18 March 1887).

35 "Minute Books," vi, 35 (28 April 1873). It is signed "Bishop \& Evans, Halifax, N.S.," and originally was placed on the axis of the centre aisle just outside the new chancel.

36 This stained glass - the first in the church - was selected by the then rector, Dr. George W. Hill, when he was in England during the late surnmer of 1872 . It was purchased from Cox \& Co. at a cost of $£ 100$ : “Minute Books," vi, 18 (28 September 1872, and 19-20 (9 October 1872). It was replaced in 1893 by a figured composition.

37 A brass eagle lectern presented in 1893 ("Minute Books," vII, 316 [17 April 1893]); a new stained glass window also presented in 1893 (Rector's Third Annual Report, Easter, 1893,12 ); a new brass and oak pulpit received in 1901 (virl [3 April 1899-16 April 1906; paginated], 98 [27 May 1901]); a new oak prayer desk presented in 1904 (viI, 260 [ 18 January 1904]); a new Communion table was given in 1905. The furnishings are those still in use. They have been supplemented only by the new organ installed on both sides of the chancel in 1908 (Ix [23 April 1906-15 January 1919; paginated], 26 [28 January 1907]: 29 [ 18 February 1907]; 79 [26 May 1908]; 86 [17 August 1908]; and 100 [ 18 January 1909]), and the new choir stalls placed in 1909, an anonymous donor having come forth to provide funds for an expressed need (IX, 101 [18 January 1909, and 123 [19 April 1909]).

38 "Minute Books," Ix, 64 (23 March 1908); 72 (20 April 1908); 76 (4 May 1908); 79 (26 May 1908); 82 (24 June 1908); 85 (20 July 1908); 86-87 (17 August 1908); and 88 
(19 October 1908). In this case, the initial impetus for the extension seems to have come from the rector (64).

39 The major concern seems to have been primarily financial: a new organ had just cost $\$ 8,750$.

40 "Minute Books," Ix, 5 (21 May 1806); x (20 January 1919-19 November 1928 [stamped pagination]), 412 (30 August 1926); and XII (28 January 1935-16 January 1950 [stamped pagination]), 80 (17 May 1937).

41 There are two watercolours. One is by Joseph E. Partridge (1797-?), active in Halifax ca. 1819-21. His "National School at Halifax, Nova Scotia," ca. 1820, now in the Public Archives of Nova Scotia, Halifax (acc. no. 1979.147.178), includes a view of St. Paul's from the northeast. See Mary Sparling and Scott Robson (ed.), Great Expectations: The European Vision in Nova Scotia, 1749-1848: An Exhibition Organized by the Art Gallery, Mount St. Vincent University, Halifax, 17 October-23 November 1980 (Halifax, 1980), 62 and no. 5-19.

The second is by William H. Eagar (1796-1839), active in Halifax from 1834 to his death. His "St. Paul's Church, Halifax," now in the Royal Ontario Museum, Toronto (acc. no. 955.218.5), shows St. Paul's from the northwest. See Mary Allodi, Canadian Watercolours and Drawings in the Royal Ontario Museum (Toronto, 1974), no. 742.

42 The earliest "photographic" view of St. Paul's-and chronologically the earliest view after the watercolours of Partridge and Eagar - is a daguerreotype by David J. Smith of ca. 1853, now in the Nova Scotia Museum, Halifax (acc. no. 75.70.2[P. 16]): see Jim Burant, "Pre-Confederation Photography in Halifax, Nova Scotia," Journal of Canadian Art History, Iv, I (1977), 29-30, fig. 4. In it St. Paul's appears to be painted a darkish colour with contrasting light (white?) trim. This was probably the result of a long delayed repainting in 1842: "Minute Books, " IV (1 March 1824-4 December 1843 [unpaginated]), 8 August 1842 (letter).

43 According to the recollection of the church guide, Mrs. Rhoda P. N. Weldon, it was "battleship grey" during the war - that would be as a result of repainting in 1937.

44 At that time the Fabric Committee "was authorized to obtain expert advice as to the best suitable and wearable colors to be used" (455 [18 February 1949]). The colour scheme first chosen was a "shade of medium gray, to be toned and warmed by $a[n]$ addition of a shade of light green. Window trim to be of light shade off the white and the cement walls to be of warm shade of sand stone" (467 [17 May 1949]). The expert was not named. Inexplicably, after the exterior was reported as almost completed (470 [25 May 1949]), it was then recorded that "the color of the exterior to be changed to rich brick color instead of dark [sic] gray as originally intended" (473 [3 June 1949]).

45 "Minute Books," xiII (13 February 1950-8 December 1958 [stamped pagination]), 386 (11 June 1962), and 389 (10 September 1962).

46 The first indication of any concern for style comes in 1957 when the matter of stained glass in the gallery windows was brought up as a result of the lower windows all being filled or reserved. Then the question of the "correct church practice in relation to our particular Georgian architecture" was raised: "Minute Books," xiII, 229 (8 A pril 1957). No further decision is recorded, but no stained glass has been placed in the gallery windows.

47 I owe this recollection to Mr. Frank Whelpley who was a member of the vestry at the time.

48 “Minute Books," xiv (12 January 1959-9 December 1968 [pagination stamped; begins at 281]), 547 (11 September 1967; 554 (11 December 1967); and 563 (29 January 1968: parish meeting). It had been repainted again in 1966 (508 [18 April 1966], and 509 [9 May 1966]).

49 Even as late as 1888 , the parish voted against its adoption; “Minute Books," viI, Easter Meeting, 2 A pril 1888.

50 "Minute Books," viI, 68 (8 November 1887), and 108 (24 September 1888). From "In the Dim Past, Easter Sunday in Halifax at St. Paul's Church over half a century ago [1845]," a reminiscence published in the Halifax Morning Herald, 25 March 1899, 6, the impression is gained that St. Paul's was proud of its adherence to eighteenth-century practices with regard to the conduct of the service.

51 "Minute Books," vin, 325 (24 April 1905); 364 (16 April 1906); IX. 198 (13 June 1910); $201-202$ (18 July 1910); 206 (15 August 1910); 209 (19 September 1920); 217 (17 October 1910: Special Meeting; motion against passed, 39 to 19); 241-42 (17 A pril 1911); 314-15 (20 January 1913); 319 (10 February 1913: Special Meeting; motion for approved, 40 to 36 ); 322 (17 February 1913); 329 (16 June 913); 342 (19 January 1914: Parish Annual Meeting; motion for lost, 17 to 24); 397 (17 January 1916: Parish Annual Meeting; motion for finally passed, 31 to 18); 403-404 (31 January 1916); 407 (16 March 1916: Special Meeting; motion against failed, 36 to 84 ); and 408 (20 March 1916). The issue had been considered even earlier ( $\mathrm{vI}, 87$ [2 April 1888]; 132 [22 April 1889]; 142 [3 May 1889]; 163 [9 December 1889]; and 183 [7 April 1890), and was then quietly "forgotten."

52 "Minute Book" for 22 November 1971-20 January 1976 (pagination later and incomplete, with some numbers duplicated, omitted, or out of sequence): 20 March 1972 (minute 24) ("broached in confidence"), 24 September 1974 (minute 181), 25 July 1975 (p. 4), 30 September 1975 (minute 242).

53 "Minute Book" for 17 July 1979-17 December 1982: 17 February 1980; 18 March 1980 (2, item 4d; see also letter to editor from H. Bethune Pryse, Halifax Mail-Star, 6 February 1980, 6; "Objections to Addition for St. Paul's Church Aired at Hearing," Halifax Mail-Star, 6 March 1980, 17; and "Church Addition Proposal Rejected," Halifax Mail-Star, 14 March 1980, 1.

54 The architectural style of St. Paul's has not always been held in high regard, especially during the mid-nineteenth century. One writer referred to it as a "wooden, loggen pile of the teachest order" ("Talk About Town," Acadian Recorder, 24 October 1857, 2), and another likened it to "an elephant with a horn on its head" (Halifax Evening Reporter, 10 November 1868,3$)$. 


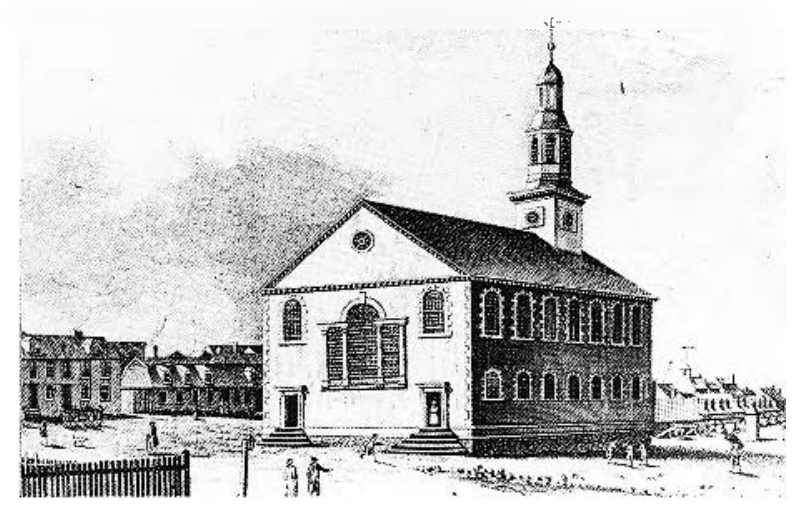

Figure 31. Jno. Fougeron. The Church of St. Paul and the Parade at Halifax, I764. Engraving (after a painting by $\mathrm{D}$. Serres based on a sketch by $\mathrm{R}$. Short), $32.3 \times$ $49.5 \mathrm{~cm}$. Halifax, St. Paul's Church. St. Paul's as it appeared in 1759 from the southeast.

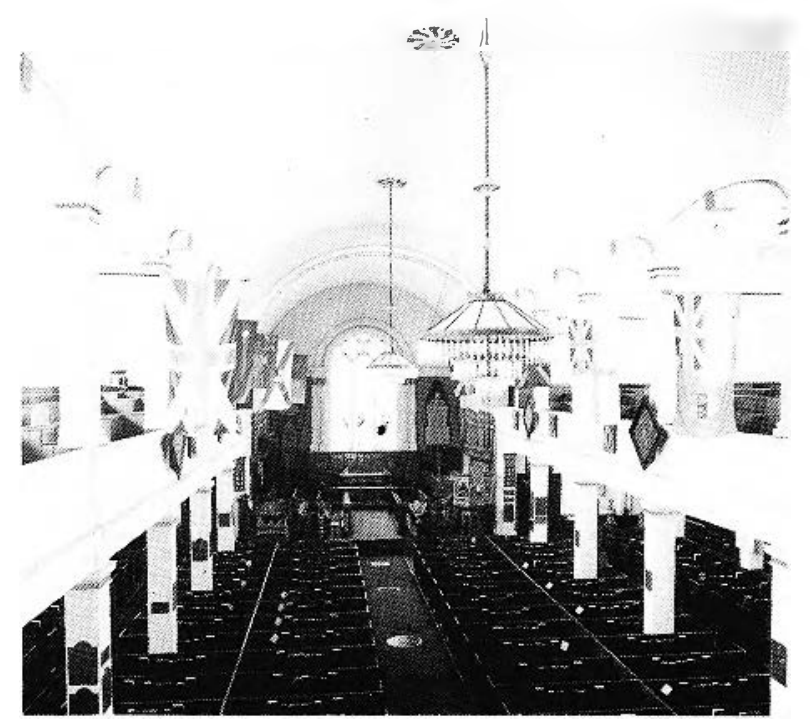

Figure 33. St. Paul's, Halifax. The interior as it appeared in 1987 (chancel of 1872) (Photo: T.U.N.S./ P. Toman).

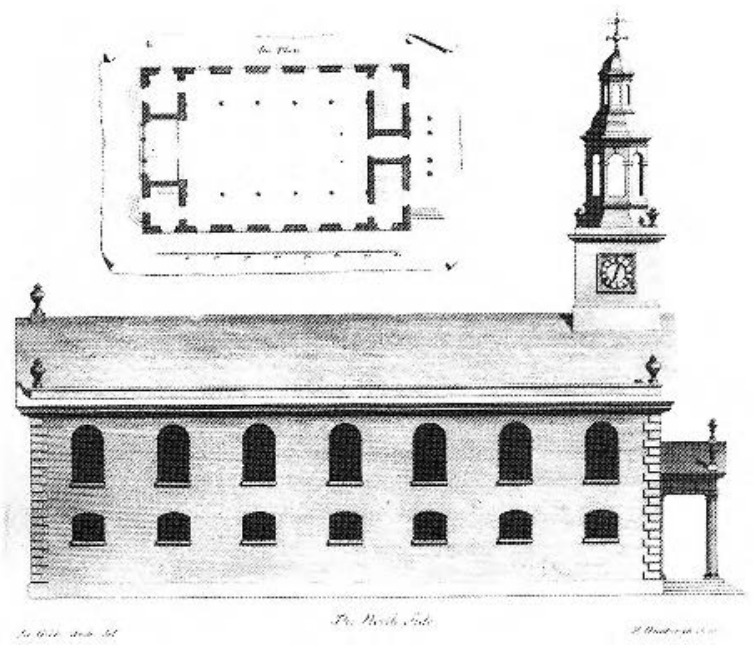

Figure 32. James Gibbs, Mary'bone Chapell [St. Peter, Vere Street], The North Side with the plan in small. Engraving (Photo: Reproduced from $A$ Book of Architecture [London, 1728], pl. xxIv).

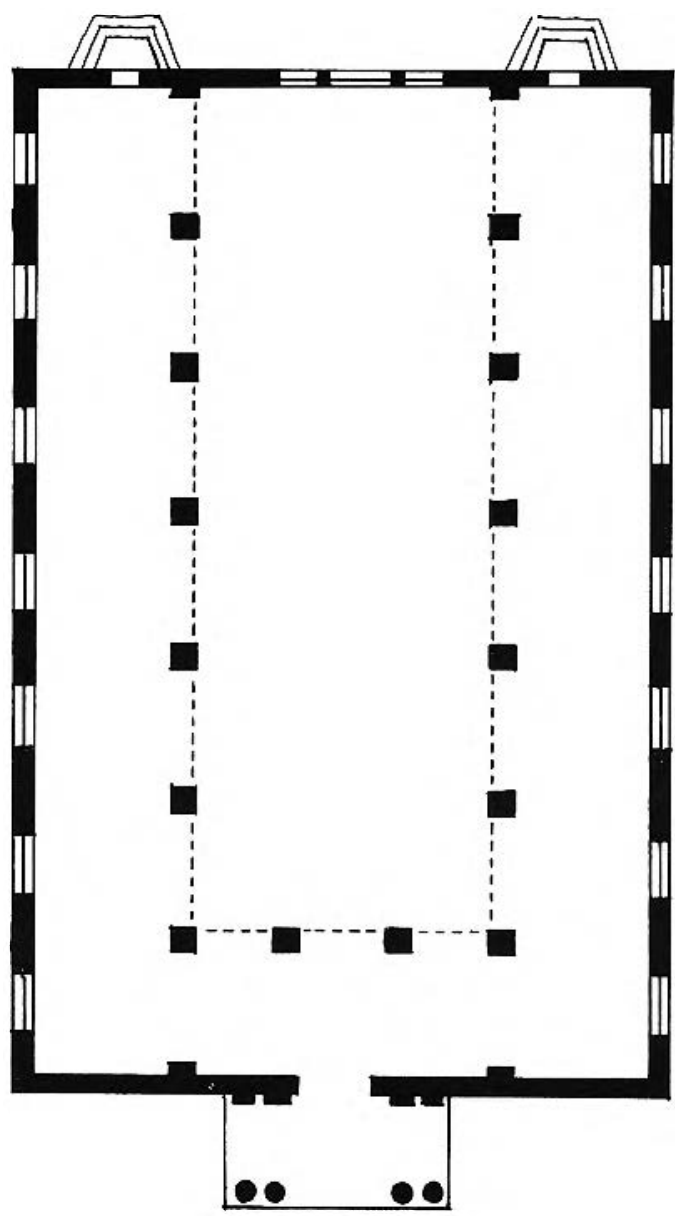

Figure 34. St. Paul's, Halifax. Reconstruction of ground plan as built in 1750 (Photo: Author). 


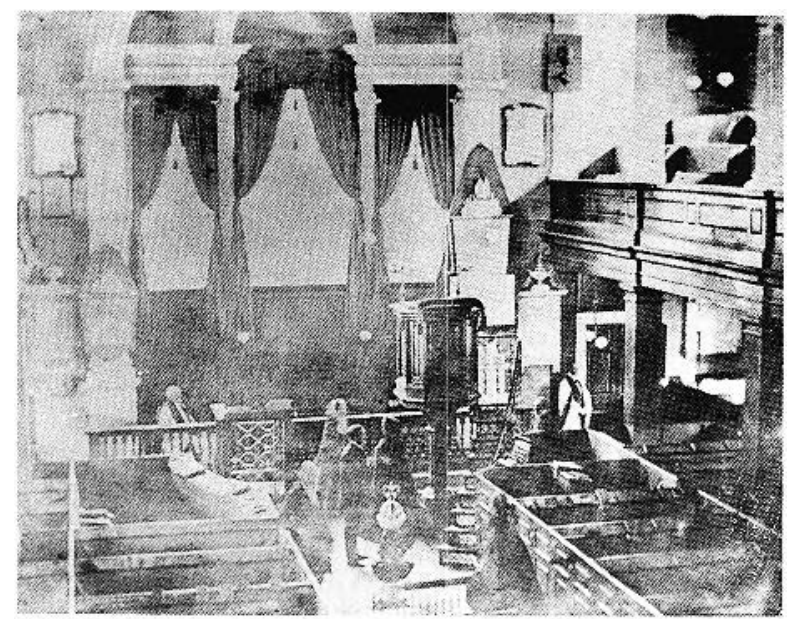

Figtre 3j. Wellington A. Chase, St. Paul's, photograph, ca. 1859-67. The sanctuary before the addition of the chancel in 1872 .

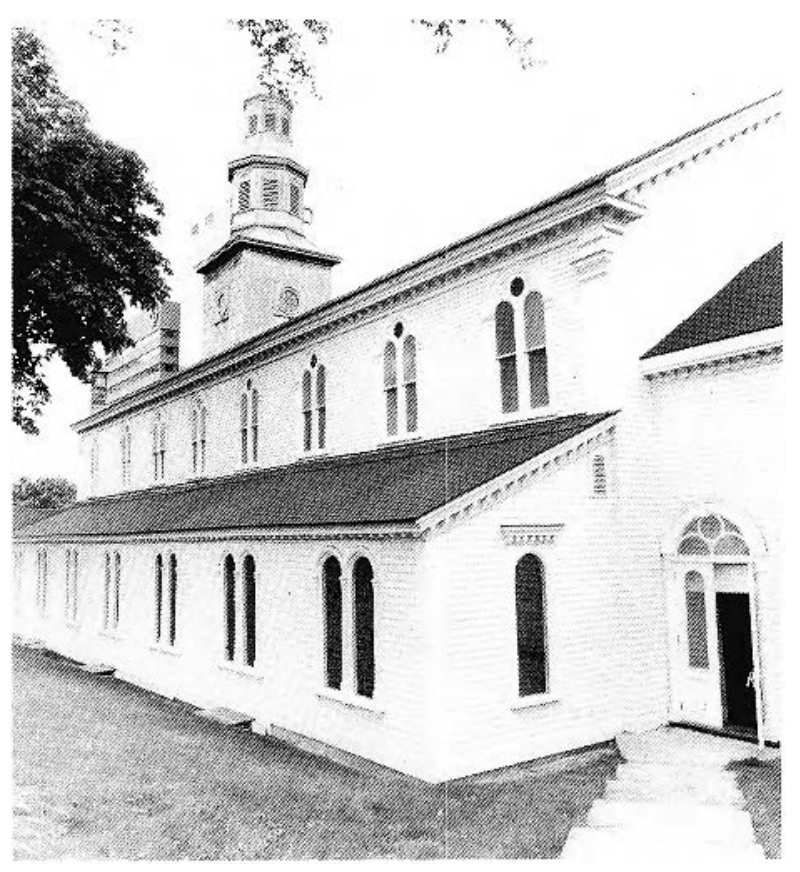

Figure 37. St. Paul's, Halifax. The west aisle of 1868 and upper windows of 1869 as they appeared in 1987 (Photo: T.U.N.S./P. Toman).

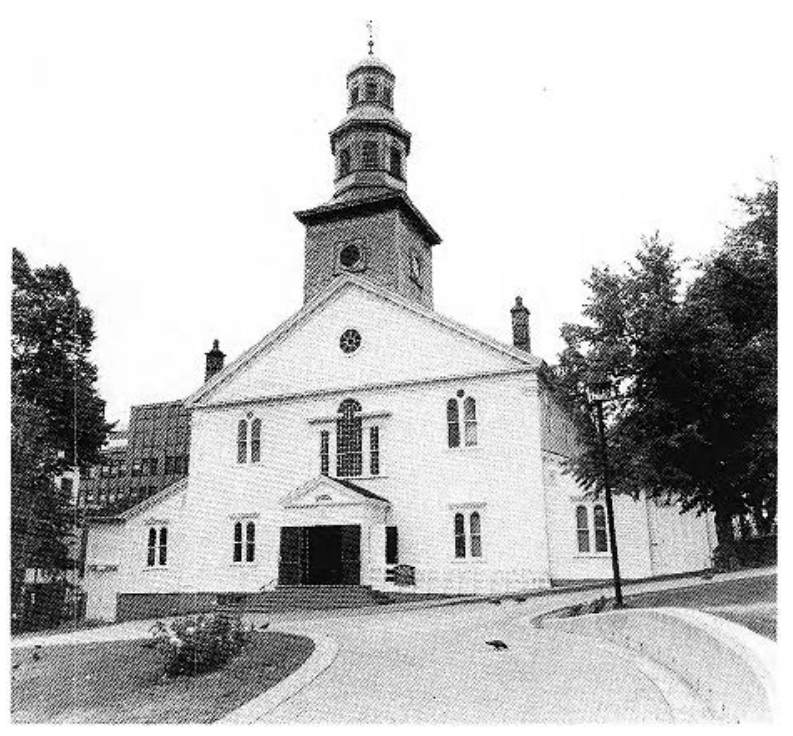

Figure 36. St. Paul's, Halifax. The (north) façade of 1812, as it appeared in 1987 (porch of the 1950s) (Photo: T.U.N.S./P. Toman).

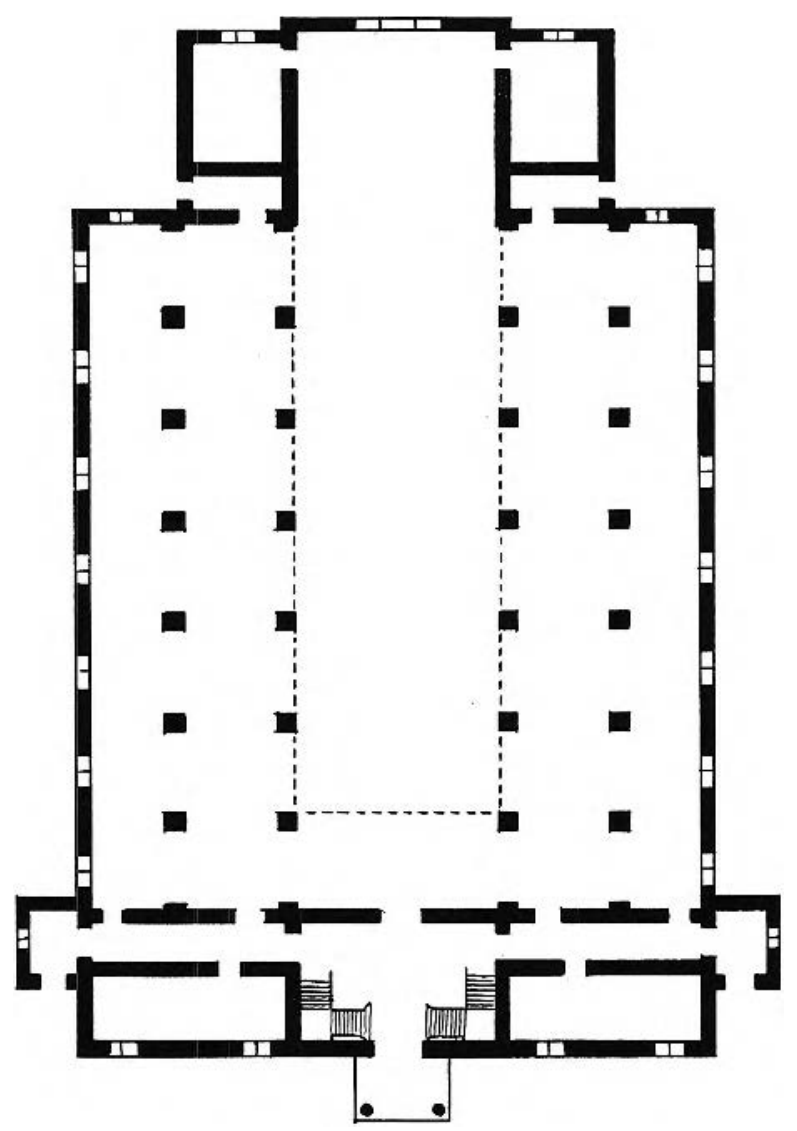

Figure 38. St. Paul's, Halifax. Reconstruction of plan after additions of 1812, 1868, and 1872 (Photo: Author). 


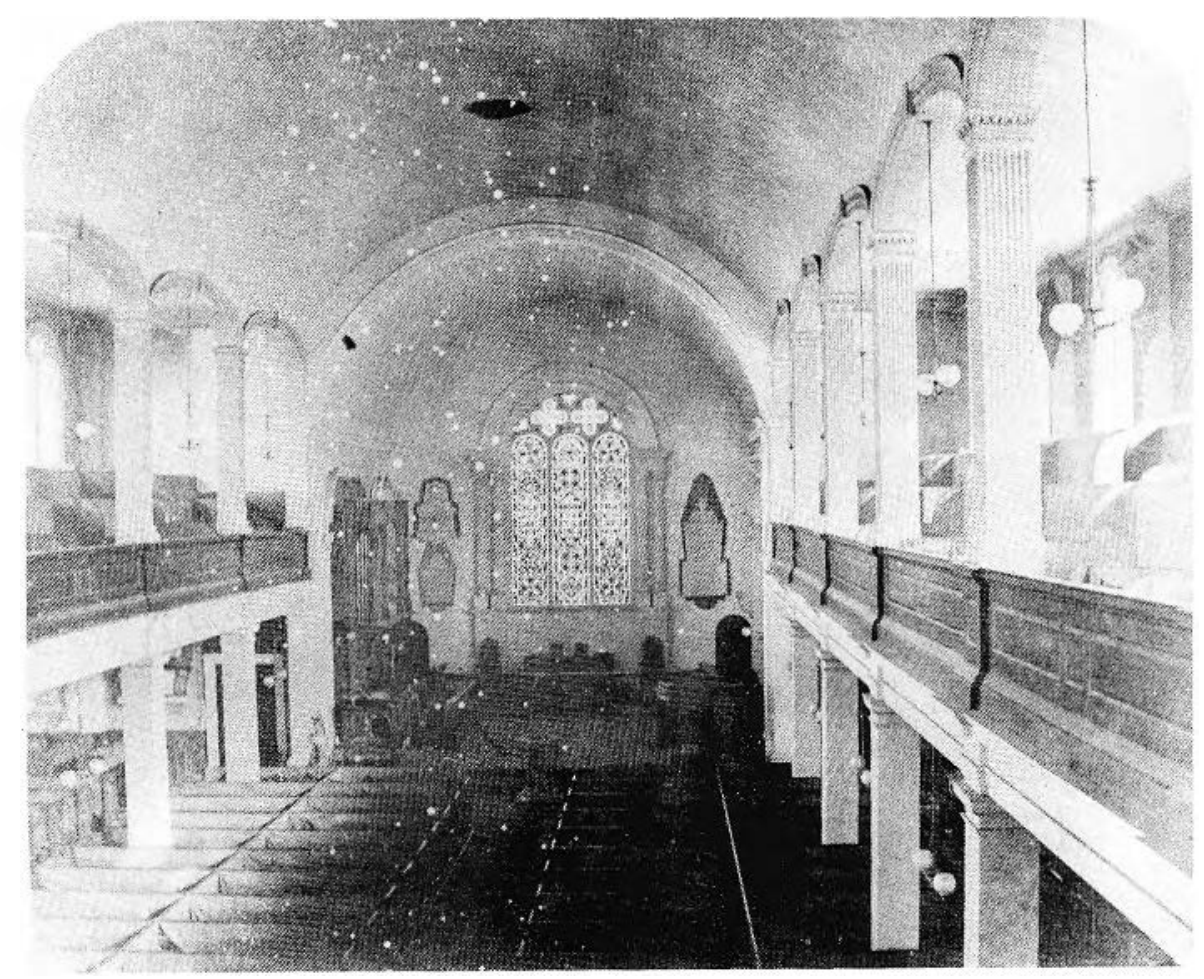

Figlre 39. Anonymous, St. Paul's, photograph, ca. 1872-75. View to south after addition of the chancel in 1872 .

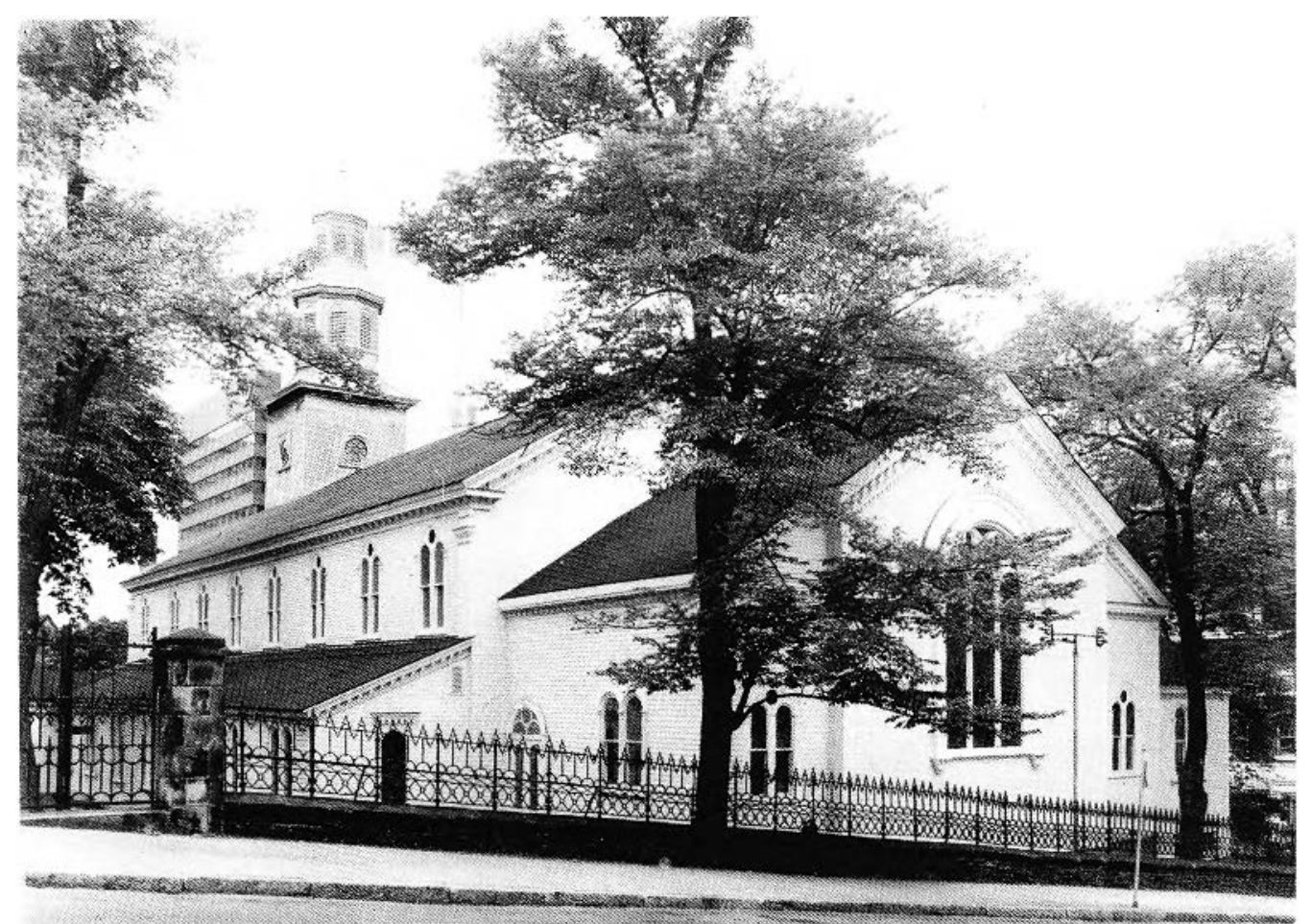

Figure 40. St. Paul's, Halifax. The chancel of 1872 (altered in 1908-1909), as it appeared in 1987 (Photo: T.U.N.S./P. Toman). 